\title{
EFFECT OF SEROTONIN AXON INJURY ON THE SOMATOSTATINERGIC SYSTEM IN RAT FRONTOPARIETAL CORTEX
}

\author{
G. Muñoz-Acedo, S. López-Sañudo and E. Arilla \\ Molecular Neuroendocrinology Unit, \\ Department of Biochemistry and Molecular Biology, \\ Medical School, University of Alcalá, \\ 28871 Alcalá de Henares, Madrid, Spain. \\ (Received in final form December 15, 1992)

\section{$\underline{\text { Summary }}$}

In order to investigate the possibility that, in the rat, some cerebral cortex somatostatin (SS) receptors may be localized presynaptically on the terminals of serotonergic neurons, serotonin [5-hydroxytryptamine, (5-HT)] neurons in the central nervous system were damaged with a local intracerebral injection of the serotonergic neurotoxin, 5,7-dihydroxytryptamine (5,7-DHT). The injection of 5,7DHT (11 $\mu \mathrm{g}$ free base dissolved in $10 \mu \mathrm{l}$ of isotonic saline containing $0.01 \%$ ascorbic acid) in rats produced an reduction by about $74 \%$ in frontoparietal cortical 5-HT content at 1 and 3 weeks after injection. These changes were associated with a significant decrease by about $30 \%$ in the total number of specific SS receptors in the frontoparietal cortex at both times studied without influencing the apparent affinity of the receptors. Together, these results suggest that a portion of the frontoparietal cortex SS receptors may be localized presynaptically on the serotonergic nerve terminals. The 5,7-DHT did not affect SS-like immunoreactivity (SSLI) levels suggesting that SS and 5-HT are not colocalized within the same neuronal elements in the rat frontoparietal cortex.

Somatostatin (SS) was the first growth hormone release inhibiting factor to be discovered (1). The highest concentrations were found in the hypothalamus (2), but SS has also been found widely throughout the central nervous system (3-6). It has been proposed as a central neurotransmitter and neuromodulator since it is highly concentrated within nerve endings (7), is released in vitro on depolarization in a calcium-dependent manner (8), and it modulates and it is modulated by monoaminergic transmission (9-12). In this regard, SS was found to facilitate, in a dose-dependent manner, the electric,-or high $\mathrm{K}^{+}$, stimulated release of serotonin [5hydroxytryptamine, (5-HT)] from rat cerebral cortex (13). In addition, SS has been shown to increase brain serotonergic turnover (14). These findings suggest that such actions are probably mediated through specific SS receptors present in the brain (15-18). To our knowledge it is unknown whether there are SS receptors located on serotonergic-containing nerve terminals in the cerebral cortex. As an initial approach to examining the posibility that, in the rat, some cerebral cortex SS receptors may be presynaptically located on the terminals of serotonergic neurons, we studied the effects of administering 5,7-dihydroxytryptamine (5,7-DHT), which induces extensive axonal degeneration of central 5-HT neurons after intraventricular or intracerebral injection in the rat (19-21), on specific SS binding to membranes from rat frontoparietal cortex. This brain region was employed here because it contains significant amounts of SS (3-6), as well as SS receptors (15-18) as well as receiving serotonergic innervation (22). This study was done at 1 and 3 weeks after 5,7-DHT administration. SS- and 5-HT-like immunoreactivity in the frontoparietal cortex 
of these rats has also been examined.

\section{Chemicals}

\section{Materials and Methods}

Synthetic Tyr ${ }^{11}$-SS and SS tetradecapeptide were purchased from Universal Biological Ltd (Cambridge, U.K.); 5,7-DHT, desmethylimipramine (DMI), bacitracin and bovine serum albumin (BSA) (fraction V) from Sigma (St. Louis, Mo U.S.A.); and carrier-free $\mathrm{Na}^{125}$ I (IMS 30, 100 $\mathrm{mCi} / \mathrm{ml}$ ) from the Radiochemical Centre (Amersham, U.K.). The rabbit antibody used in the radioimmunoassay technique was purchased from the Radiochemical Centre (Amersham, Bucks, U.K.). This antiserum was raised in rabbits against SS-14 conjugated to bovine serum albumin and is specific for SS but it does not distinguish between SS-14, SS-25 and SS-28. All other chemicals were reagent grade.

\section{Experimental animals}

Adult Wistar rats, initially weighing approximately $200 \mathrm{~g}$, were maintained on a 12-hr light/12-hr dark cycle; with food and water ad libitum. The chemical destruction of ascending serotonergic neurons was accomplished under ether anesthesia, by local intracerebral injection of 5,7-DHT $(11 \mu \mathrm{g}$ of free base in $10 \mu \mathrm{l}$ of isotonic saline containig $0.01 \%$ ascorbic acid to prevent oxidation of the 5,7-DHT), according to a modification of the method described by Björklund et al (23). The injection of 5,7-DHT was carried out using a stainless steel cannula (outer diameter: $0.21 \mathrm{~mm}$; inner diameter $0.13 \mathrm{~mm}$ ) acutely implanted at the following coordinates: A: $2.6 \mathrm{~mm}$, $\mathrm{L}: 0.4 \mathrm{~mm}, \mathrm{H}: 2.2 \mathrm{~mm}(24)$. In order to protect noradrenergic neurons from the neurotoxic action of 5,7-DHT, desmethylimipramine (DMI) $(25 \mathrm{mg} / \mathrm{kg}$ intraperitoneally) was administered $45 \mathrm{~min}$ before the injection of the neurotoxic agent (25). Control rats were treated identically except that no neurotoxin was injected. The rats were decapitated at 1 and 3 weeks after the injection. The brain was rapidly removed and frontoparietal cortex was dissected over ice according to the method of Glowinsky and Iverssen (26).

\section{Measurements of monoamines and SS}

To assess the destruction of serotonergic neurons in rats treated with the neurotoxin 5,7DHT, as well as the protection of noradrenergic neurons by pretreatment with DMI, frontoparietal cortex 5-HT and noradrenaline (NA) contents of control and treated rats were measured by high-performance liquid chromatography (HPLC) with electrochemical detection (27). SS was extracted from the frontoparietal cortex following the method of Patel and Reichlin (28). SSLI content was measured by a modified specific radioimmunoassay method (28), with a sensitivity limit of $10 \mathrm{pg} / \mathrm{ml}$. Protein concentration was estimated by the method of Lowry et al. (29) using bovine serum albumin as a standard. Separation of bound and free neuropeptide was accomplished by addition of $1 \mathrm{ml}$ dextran coated charcoal (dextran $0.2 \% \mathrm{w} / \mathrm{v}$; charcoal $2 \% \mathrm{w} / \mathrm{v}$ ). The dilution curve of the frontoparietal cortex was paralled to the standard curve. The intra- and inter-assay variation coefficients were $5,9 \%$ and $9,1 \%$, respectively.

\section{Binding assay}

$\mathrm{Tyr}^{11}$-SS was radioiodinated by the chloramine-T method (30). The tracer was purified in a Sephadex G-25 coarse column (1x100) wich had been equilibrated with $0.1 \mathrm{M}$ acetic acid containing bovine serum albumin $0.1 \%$ (w/v). Specific tracer radioactivity was about $380 \mathrm{Ci} / \mathrm{g}$. Frontoparietal cortex membranes were prepared as described by Reubi et al (31). Proteins were assayed by the method of Lowry et al (29), with bovine serum albumin as a standard. Specific 
SS binding was measured according to the modified method of Czernik and Petrack (32). The membranes $(0.15 \mathrm{mg}$ protein $/ \mathrm{ml})$ were incubated in $250 \mu \mathrm{l}$ of a medium containing $50 \mathrm{mM}$ Tris$\mathrm{HCl}$ buffer ( $\mathrm{pH} 7.5$ ), $5 \mathrm{mM} \mathrm{MgCl}, 0.2 \%$ (w/v) bovine serum albumin and $0.1 \mathrm{mg} / \mathrm{ml}$ bacitracin

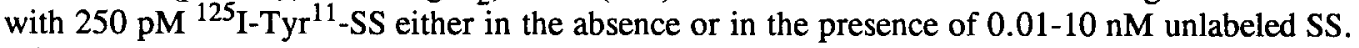
After $60 \mathrm{~min}$ incubation at $30^{\circ} \mathrm{C}$, the free radioligand was separated from the bound radioligand by centrifugation at $12000 \mathrm{~g}$ (Beckman microcentrifuge) for $1.5 \mathrm{~min}$ and the resultant pellet was counted in a Beckman gamma counter. Nonspecific binding, i.e., binding occurring in the presence of a high concentration $\left(10^{-7} \mathrm{M}\right)$ of unlabelled SS, represented about $20 \%$ of the binding observed in the absence of native peptide and was subtracted from the total bound radioactivity in order to obtain the corresponding specific binding. The inactivation of ${ }^{125} \mathrm{I}_{-} \mathrm{Tyr}^{11_{-}} \mathrm{SS}$ in the incubation medium after exposure to membranes was studied by observing the ability of the peptide to rebind to fresh membranes (33).

\section{Data analysis}

Saturation curves were plotted according to the methods of Scatchard (34). Kd and Bmax were determined by linear regression analysis. The student's $\underline{t}$ test for unpaired variables was employed to asses differences between control and experimental groups. Results were given in all cases as the mean $\pm S E M$.

\section{Results}

Destruction of the ascending serotonergic pathways by the intracerebral injection of 5,7DHT resulted in an approximately $74 \%$ depletion of 5-HT in the frontoparietal cortex at 1 and 3 weeks after the drug treatment (Table 1). No significant depletion of NA ocurred in the cortex of 5,7-DHT rats (90-95\% of control values, data not shown).

The administration of 5,7-DHT or DMI did not affects SSLI levels in the frontoparietal cortex in comparison with the control group at either time studied (92-98\% of control values, data not shown).

\section{TABLE I}

Effect of 5,7-dihydroxytryptamine (5,7-DHT) and desmethylimipramine (DMI) on the levels of serotonin [5-hydroxytryptamine, $(5-\mathrm{HT})]$ in the frontoparietal cortex of the rat at one and three weeks after administration.

\begin{tabular}{lcc}
\hline & \multicolumn{3}{c}{ Frontoparietal cortex } \\
\cline { 2 - 3 } Groups & 1 week & 3 weeks \\
\hline Control & $410.1 \pm 12.5$ & $425.6 \pm 13.8$ \\
DMI+5,7-DHT & $105 \pm 10.2 *$ & $110 \pm 9.8 *$
\end{tabular}

The results are expressed as means \pm S.E.M. in ng of 5-HT/g wet weight of tissue of six rats in each group. Statistical comparison versus controls: ${ }^{*} \mathrm{p}<0.0001$.

Frontoparietal cortex membranes from the experimental groups bound ${ }^{125} \mathrm{I}_{-} \mathrm{Tyr}^{11}$-SS in a time-dependent fashion; an apparent equilibrium was observed between 50 and 120 min at $30^{\circ} \mathrm{C}$ 
(data not shown). All subsequent binding experiments were therefore conducted at $30^{\circ} \mathrm{C}$ for 60 min.

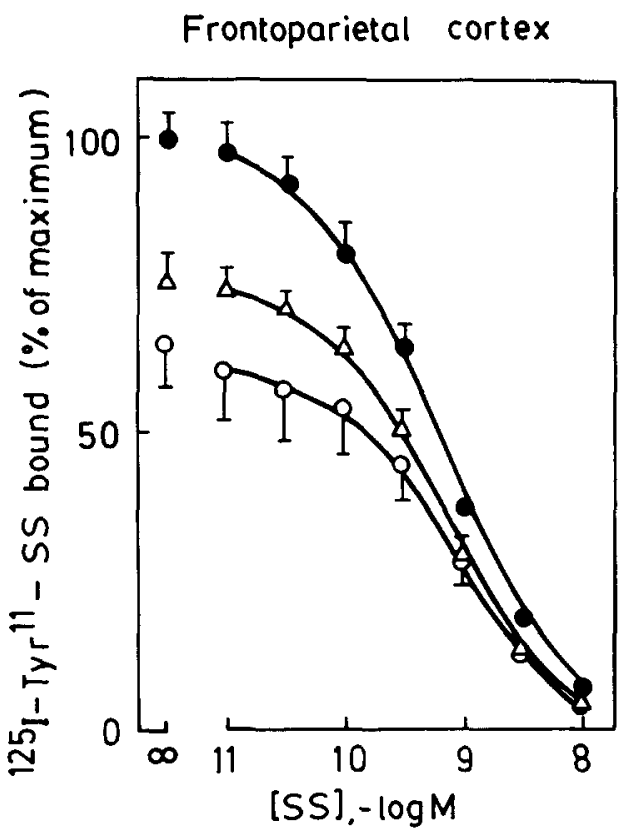

FIG. 1

Competitive inhibition of specific ${ }^{125} \mathrm{I}^{-T y r}{ }^{11}$-somatostatin $\left({ }^{125} \mathrm{I}-\mathrm{Tyr}^{11}-\mathrm{SS}, 250 \mathrm{pM}\right)$ binding by unlabeled SS to frontoparietal cortex membranes. Membranes $(0.15 \mathrm{mg}$ protein $/ \mathrm{ml}$ ) were incubated for $60 \mathrm{~min}$ at $30^{\circ} \mathrm{C}$ in the presence of $250 \mathrm{pM}{ }^{125} \mathrm{I}$ Tyr ${ }^{11}$-SS and increasing concentrations of native peptide. Points correspond to control animals $(\bullet)$ and 5,7-DHT-treated rats at $1(\Delta)$ and $3(0)$ weeks after 5,7DHT injection. Each point is the mean of five rats in each group.

Peptide degradation was determined in all the preparations to rule out the possibility of different SS degrading activities which might have affected the interpretation of the results. Membranes from the frontoparietal cortex showed a similar peptide degradation capacity and the values varied by no more than $10 \%$ among all the experimental groups.

Increasing concentrations of unlabeled SS competitively inhibited the specific binding of ${ }^{125} \mathrm{I}_{-\mathrm{Tyr}}{ }^{11}$-SS to rat frontoparietal cortex membranes in the preparations from both control and 5,7 DHT-treated rats. At 1 and 3 weeks after the 5,7-DHT injection a decrease in the specific binding of the ${ }^{125} \mathrm{I}_{-} \mathrm{Tyr}^{11}$-SS to membranes from the frontoparietal cortex was observed (Fig. 1).

Sctchard plots of the binding of tracer to membranes from frontoparietal cortex indicated that intracerebral injection of 5,7-DHT was associated with a decrease in the number of SS receptors in the frontoparietal cortex without affecting the affinity constant at either time studied (Fig. 2 and Table II). DMI alone had no observable effect on the binding of ${ }^{125}{ }^{2}-\mathrm{Tyr}^{11}$-SS to membranes from frontoparietal cortex (Table II). 


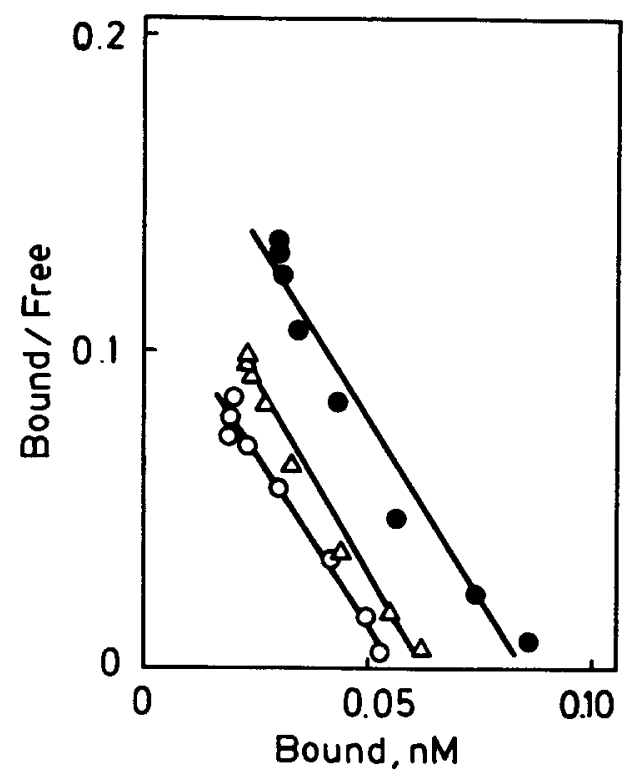

FIG.2

Scatchard plots of specific ${ }^{125}$-I-Tyr ${ }^{11}$-somatostatin $\left({ }^{125}\right.$-I-Tyr ${ }^{11}-\mathrm{SS}, 250 \mathrm{pM}$ ) binding to frontoparietal cortex membranes $(0.15 \mathrm{mg}$ protein $/ \mathrm{ml})$ from controls $(\bullet)$ and 5,7-DHT-treated rats $1(\Delta)$ and $3(0)$ weeks following 5,7-DHT injection. Each point is the mean of five rats in each group. The corresponding equilibrium binding parameters are incluided in Table II.

TABLE II

Effect of 5,7-dihydroxytryptamine (5,7-DHT) and desmethylimipramine (DMI) on equilibrium parameters of ${ }^{125} \mathrm{I}_{-} \mathrm{Tyr}^{11}$-somatostatin $\left({ }^{125}{\mathrm{I}-\mathrm{Tyr}^{11}}^{11}\right.$-SS) binding to frontoparietal cortex membranes.

\begin{tabular}{|c|c|c|}
\hline \multirow[b]{2}{*}{ Groups } & \multicolumn{2}{|c|}{ Frontoparietal cortex } \\
\hline & 1 week & 3 weeks \\
\hline \multicolumn{3}{|l|}{ Control } \\
\hline $\mathrm{Kd}$ & $0.46 \pm 0.05$ & $0.42 \pm 0.06$ \\
\hline$B \max$ & $587 \pm 28$ & $540 \pm 23$ \\
\hline \multicolumn{3}{|c|}{$\mathrm{DMI}+5,7-\mathrm{DHT}$} \\
\hline $\mathrm{Kd}$ & $0.42 \pm 0.04$ & $0.48 \pm 0.07$ \\
\hline$B \max$ & $418 \pm 28 *$ & $381 \pm 21 * *$ \\
\hline \multicolumn{3}{|l|}{ DMI } \\
\hline $\mathrm{Kd}$ & $0.45 \pm 0.03$ & $0.43 \pm 0.05$ \\
\hline$B \max$ & $553 \pm 25$ & $565 \pm 27$ \\
\hline
\end{tabular}

$\mathrm{Kd}$ is the dissociation constant, $\mathrm{nM}$; Bmax is the binding capacity, from fentomoles of SS bound per $\mathrm{mg}$ protein. Each value is the mean \pm S.E.M. of five rats in each group. Statistical comparison versus controls: ${ }^{*} \mathrm{p}<0.003 * * \mathrm{p}<0.001$. 


\section{Discussion}

The injection of 5,7-DHT severely decreased the level of 5-HT (by about 74\%) in the rat frontoparietal cortex while leaving the NA contents essentially unchanged in agreement with previously published values (19-21). Thus, the innervation of this brain region by 5-HT axons was nearly abolished by 5,7-DHT, whereas the NA axons remained essentially intact.

The SSLI content in the frontoparietal cortex in the control rats was similar to those previously reported by others (35-36). The treatment with 5,7-DHT did not affect SSLI levels in the frontoparietal cortex in comparison with the control group at either time studied. This suggests that SS and 5-HT are not colocalized in the same neuronal elements in the rat frontoparietal cortex.

The Scatchard analysis of the stechiometric data suggest the existence of only one type of SS receptor. This finding agrees with some studies in rat brain membranes $(16,32,35)$ but differs from other more recent data $(18,37)$. It is conceivable that the use of small SS analogues (38) or their labelling with different isotopes (18) might explain this difference.

The fact that the injection of 5,7-DHT decreased the level of 5-HT (by about 74\%) and the number of SS receptors (by about 30\%) in the frontoparietal cortex, together with the evidence that SS exerts a presynaptic control on the release (13) and turnover (14) of cortical 5HT, suggests that some of the frontoparietal cortex SS receptors could be located on the serotonergic neuronal terminals. The difference in magnitude between 5-HT depletion and the decrease in SS receptors also raises the possibility that the receptors could be present on neuronal terminal membrane 'ghosts' that remain after 5,7-DHT treatment. Apart from presynaptic receptors on 5-HT afferents, an alternative explanation for the loss of SS receptors is the possibility of transsynaptic effects on receptor expression.

The presence of SS receptors on serotonergic neurons in the frontoparietal cortex might provide a basis for the better understanding of the basic mechanism of numerous complex cerebral activities such as learning, sleep and mood, $(6,38)$ which are thought to be involved in both neuronal systems.

\section{Acknowledgements}

This work was supported by a grant from the Dirección General de Investigación Científica y Técnica (PM91-0027). The authors thank Carol F. Warren from the Alcalá de Henares University Institute of Education Sciences for her editorial help.

\section{$\underline{\text { References }}$}

1. P. BRAZEAU, W. VALE, R. BURGUS, N. LING, M. BUTCHER, J. RIVIER and R. GUILLEMIN, Science 129 77-79 (1973).

2. M. BROWNSTEIN, A. ARIMURA, H. SATO, A.V. SCHALLY and J.S.KIZER, Endocrinology 96 1415-1461 (1975).

3. J.C.W. FINLEY, J.L. MADERDRUT, L.J. ROGER and P. PETRUSZ, Neuroscience 6 2173-2192 (1981).

4. J.H. MORRISON, R. BENOIT, P.J. MAGISTRETTI and F.E. BLOOM, Brain Res. 262 344-351 (1983).

5. R.M. LECHAN, R.H. GOODMAN, M. ROSENGLATT, S. REICHLIN and J.F. HABENER, Proc. Nat. Acad. Sci. USA, $\underline{80} 2788-2784$ (1983).

6. J. EPELBAUM, Prog. Neurobiol. 27 63-100 (1986). 
7. J. EPELBAUM, P. BRAZEAU, D. TSANG, J. BRAWER and J.B. MARTIN, Brain Res. 126 309-323 (1977).

8. G.W. BENNET, J.A. EDWARDSON, D. MARCANO DE COTTE, M. BERELOWITZ, B. PIMSTONE and G.H. KRONHEIM, J. Neurochem. 22 1127-1130 (1979).

9. A. NEGRO VILAR, S.R. GEDA, A. ARIMURA and S.M. Mc CANN, Life Sci. 23 1943-1948 (1978).

10. M.F. CHESSELET and T.D. REISINE, J. Neurosci. $\underline{3}$ 232-236 (1983).

11. B.M. LEWIS, C. DIEGUEZ, M. LEWIS, R. HALL and M.F. SCANLON, Endocrinology $\underline{119} 1712-1717$ (1986).

12 L.J. THAL, K. LAING, S.J. HOROWITZ and M.H. MAKMAN, Brain Res. 372 205-209 (1986).

13. S. TANAKA and A. TSUJIMOTO, Brain Res. 208 219-222 (1981).

14. J.A. GARCIA SEVILLA, T. MAGNUSON and A. CARLSSON, Brain Res. 155 159-164 (1978).

15. C.B. SRIKANT AND J.C. PATEL, Proc. Natl. Acad. Sci. USA. 78 3930-3934 (1981).

16. J. EPELBAUM, L. TAPIA-ARANCIBIA, C. KORDON and A. ENJALBERT, J. Neurochem. 38 1515-1523 (1982).

17. A.J. CZERNICK and B. PETRACK, J. Biol. Chem. 258 5525-5530 (1983).

18. D.R. WEIGHTMAN, C.A. WHITFORD, C.R. SNELL, B.H. HIRST, D.E. BRUNDISH and P.A. KENDALL-TAYLOR, Neurosci. Lett. 55 161-166 (1985).

19. H.G. BAUMGARTEN, A. BJÖRKLUND, L. LACHENMAYER and A. NOBIN, Acta Physiol. Scand. Suppl. 391 1-22 (1973).

20. J.H. JACOBY, L.D. LYTLE and M.F. NELSON, Life Sci. 14 909-919 (1974).

21. A. BJÖRKLUND, H.G. BAUMGARTEN and A. RENSCH, J. Neurochem. 24 833-835 (1975).

22. E.C. AZMITIA and M. SEGAL, J. Comp. Neurol. 179 641-668 (1978).

23. A. BJORKLUND, A. NOBIN and U. STENEVI, Z. Zellforsch. 145 479-501 (1973).

24. D. ALBE-FESSARD, F.STUTINSKY and S. LIBOUBAN, Atlas Stéreotaxique du Diencéphale du Rat Blanc. CNRS, 1966.

25. C.L. MELCHIOR and B. TABAKOFF, Pharmacol. Biochem. Behav. 24 955-961 (1986).

26. J. GLOWINSKI and L.L. IVERSEN, J. Neurochem. 13 655-699 (1966).

27. G. SPERK, J. Neurochem. 38 840-843 (1982).

28. J.C. PATEL and S. REICHLIN, Endocrinology 102 523-531 (1978).

29. O.H. LOWRY, N.J. ROSEBROUGH, A.L. FARR and R.J. RANDALL, J. Biol. Chem. 193 265-275 (1952).

30. F.C. GREENWOOD, W.M. HUNTER and J.S. GLOWER, Biochem. J. $\underline{89}$ 114-123 (1963).

31. J.C. REUBI, M.H. PERRIN, J.E. RIVIER and V. VALE, Life Sci. 28 2191-2198 (1981).

32. A.J. CZERNIK and V. PETRACK, J. Biol. Chem. 285 5525-5530 (1983).

33. G. AGUILERA, D.S. PARKER and K.J. CATT, Endocrinology 111 1376-1384 (1982).

34. G. SCATCHARD, Ann. N.Y. Acad. Sci. 51 669-671 (1949).

35. C.B. SRIKANT and J.C. PATEL, Proc. Natl. Acad. Sci. USA 78 3930-3934 (1981).

36. A. PITKANEN, J. SIRVIO, J. JOLKKONEN and P. RIEKKINEN, Neuropeptides 7 6371 (1986).

37. J.C. REUBI, Neurosci. Lett. 49 259-263 (1984).

38. B. SREBRO and S.A. LORENS, Brain Res. $\underline{89}$ 303-325 (1975). 